\title{
RESEARCH ON CONSTRUCTION AND SIZING OF THE METAL STRUCTURE OF A WINDING INSTALLATION
}

\author{
Marin-Silviu NAN ${ }^{1}$, Dorina BĂDIȚ̆ (POPESCU) $^{2}$, Danut GRECEA ${ }^{3}$ \\ Cosmin VITAN ${ }^{1}$, Bogdan BRĂNIȘTEANU ${ }^{3}$ \\ ${ }^{1}$ University of Petrosani, Romania \\ ${ }^{2}$ Colegiu Tehnic "Constantin Brancus" Petrila, Romania \\ ${ }^{3}$ National Institute for Research and Development in Mine Safety and Protection to Explosion - INSEMEX, \\ Petrosani, Romania \\ e-mail: vitan.daniel.cosmin@gmail.com
}

\begin{abstract}
The paper focuses on the design of the metal tower for the sinking of Netiş deventilating shaft in Râul Mare Retezat hydro-energetic setup. The analytical calculation of sizing and verification of the metal structure is doubled by the graphic simulation with speciality software, in view of obtaining results as close as possible to the real exploitation conditions of the tower. The tower of the deventilating shaft is considered to be a temporary construction, and its component parts will be decommissioned once the sinking is finalized. The tower is made up of metal structures in four transoms, 3 being mounted with junction plates and screws, the fourth being the roof.
\end{abstract}

KEYWORDS: winging installation, metal structures, design and simulation, de-ventilating shaft

\section{Introduction}

To improve the present utilization and exploitation conditions in Râul Mare Retezat hydroenergetic setup, it is necessary to sink a de-ventilating shaft; this is the object of the present paper. The deventilating shaft is a classical mining working, similar to those generally used for the extraction of useful mineral substances; what is particular in this case is the position conditions in a mountain area of the winding machine.

De-ventilating shafts are hydro technical workings intended to remove air from underground galleries, in order to increase and make even the flow of the handled water. This phenomenon is translated in supplementing the electricity production, determined by the reduction of the air resistance in case of water flow in the head race [1].

\section{Establishing the load forces}

The winding tower is stressed in time due to the hoisting of the sterile extracted during the sinking of the de-ventilation shaft. In the following, the conditions for the analytical calculation will be defined and materialized [1].

Thus, in Fig. 1 the calculation model is presented with the geometric dimensions of the tower to determine its state of load.

Determination of the position of the weight centre of the tower on the three geometric axes is calculated according to the weights of the transoms, the positions of the weight centres of each transom, the weight of the pulleys and their weight centres. The total weight of the tower in $\mathrm{N}$ is:

$$
\mathrm{G}=\mathrm{G}_{\mathrm{ti}}+\mathrm{G}_{\mathrm{m}}+\mathrm{G}_{\mathrm{ts}}+\mathrm{G}_{\mathrm{a}}+\mathrm{G}_{\mathrm{ps}}+2 \cdot \mathrm{G}_{\mathrm{ts}}+\mathrm{G}_{\mathrm{pd}}+\mathrm{G}_{\mathrm{mm}}+4 \cdot \mathrm{G}_{\mathrm{m} 6}=2.347 \times 10^{5}
$$

where: $\mathrm{G}_{\mathrm{ti}}$ - lower transom weight, in $\mathrm{N} ; \mathrm{G}_{\mathrm{m}}$ intermediary transom weight of the tower, in $N ; \mathrm{G}_{\mathrm{ts}}$ upper transom weight, in $\mathrm{N} ; \mathrm{G}_{\mathrm{ps}}$ - weight of the upper platform of the tower, in $\mathrm{N} ; \mathrm{G}_{\mathrm{a}}$ - tower roof weight, in
$\mathrm{N} ; \mathrm{G}_{\mathrm{ts}}$ - weight of the stair's transom of the tower, in $\mathrm{N} ; \mathrm{G}_{\mathrm{pd}}$ - weight of the tower's discharge platform, in $\mathrm{N} ; \mathrm{G}_{\mathrm{mm}}$ - weight of the 2000 pulley with support, in $\mathrm{N} ; \mathrm{G}_{\mathrm{m} 6}$ - weight of the 600 pulley, in $\mathrm{N}$. 


\section{THE ANNALS OF "DUNAREA DE JOS” UNIVERSITY OF GALATI \\ FASCICLE IX. METALLURGY AND MATERIALS SCIENCE \\ $\mathrm{N}^{\circ} .2$ - 2021, ISSN 2668-4748; e-ISSN 2668-4756 \\ Article DOI: https://doi.org/10.35219/mms.2021.2.02}

Position of the tower's weight centre, in $\mathrm{mm}$ :

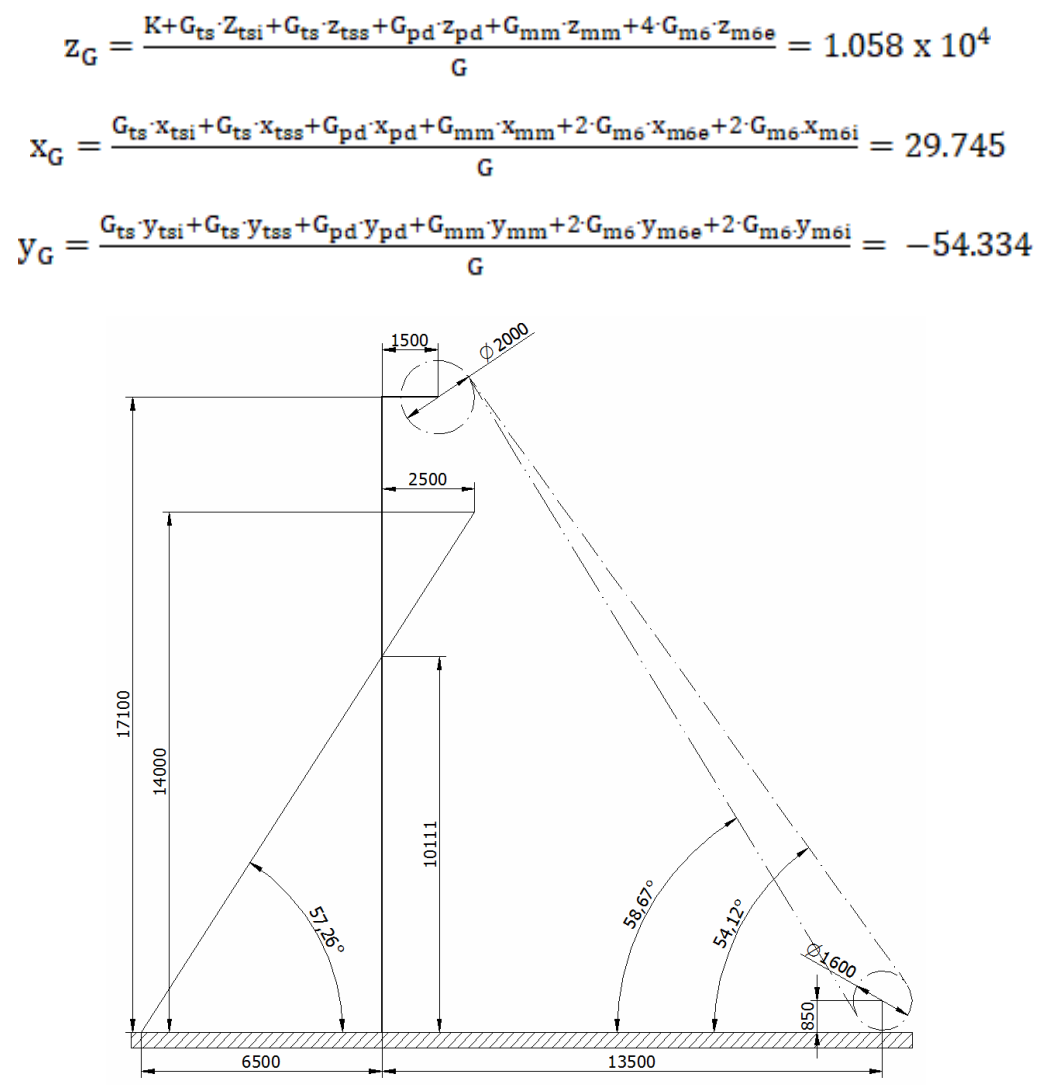

Fig. 1. Calculation model

In order to establish the maximum charging load of the tower, the inclination angle of the cable and anchor will be used, the height up to the pulley axis, the distance from the pulley axis to the tower axis, the weighs of the mobile bridge, the gripper trolley, the gripper, the useful load, weight of the cylinder, of the cable, together with the minimum and maximum length of the cable.[5]

Determination of the maximum load at the launching of the mobile bridge is determined with the formula:

$$
\mathrm{S}=\mathrm{G}_{\mathrm{pm}}+\mathrm{G}_{\mathrm{tg}}+\mathrm{G}_{\mathrm{g}}+\mathrm{G}_{\mathrm{iu}}+\mathrm{G}_{\mathrm{c}}+\mathrm{g}_{\mathrm{cab}}{ }^{*} \mathrm{l}_{\mathrm{c}}=5.568 \times 10^{4}
$$

where: $\mathrm{G}_{\mathrm{pm}}$ - weight of the mobile bridge, in $\mathrm{N} ; \mathrm{G}_{\mathrm{tg}}$ weight of the gripper trolley, in $N ; \mathrm{G}_{g}$ - weight of the gripper, in $\mathrm{N} ; \mathrm{G}_{\mathrm{iu}}$ - weight of the useful load, in $\mathrm{N} ; \mathrm{G}_{\mathrm{c}}$ - weight of the cylinder, in $\mathrm{N}$; $\mathrm{g}_{\text {cab }}$ - specific weight of the $\Phi 25 \mathrm{~mm}$ cable, in $\mathrm{N} / \mathrm{ml} ; \mathrm{l}_{\mathrm{c}}$ - minimum length of the cable, from the pulley to the bridge, in $\mathrm{m}$.
Determination of the load vertically of the rocks taken out with the skip, is defined by the weight of the skip, transport of the materials taken out by skips, the weight of the skip, the weight of the safety hook, the weight of e-169 device, the weight of the slide carriage and of the skip load, all in N.

$$
\mathrm{S}_{\mathrm{t}}=\mathrm{G}_{\mathrm{ch}}+\mathrm{G}_{\mathrm{cr}}+\mathrm{G}_{\mathrm{E}}+\mathrm{G}_{\mathrm{sg}}+\mathrm{G}_{\mathrm{ic}}+\mathrm{g}_{\mathrm{cab}}{ }^{\circ} \mathrm{l}_{\mathrm{cm}}=2.07 \times 10^{4}
$$

where: $\mathrm{G}_{\mathrm{ch}}-0.75 \mathrm{~m}^{3}$ skip weight, in $\mathrm{N} ; \mathrm{G}_{\mathrm{cr}}$ - safety hook weight, in $\mathrm{N} ; \mathrm{G}_{\mathrm{E}}-\mathrm{E}-169$ device weight, in $\mathrm{N}$; $\mathrm{G}_{\mathrm{sg}}$ - slide carriage weight, in $\mathrm{N} ; \mathrm{G}_{\mathrm{ic}}$ - skip load weight, in $\mathrm{N} ; 1_{\mathrm{cm}}$ - maximum cable length, from the pulley to E-169, in $\mathrm{m}$.
Determination of the tower strain vertically and horizontally, statically and dynamically, in $\mathrm{N}$, is influenced by the dynamic coefficient of the winding installation, which is equal to 1.6. 


\section{THE ANNALS OF "DUNAREA DE JOS” UNIVERSITY OF GALATI \\ FASCICLE IX. METALLURGY AND MATERIALS SCIENCE \\ $\mathrm{N}^{\circ} .2$ - 2021, ISSN 2668-4748; e-ISSN 2668-4756 \\ Article DOI: https://doi.org/10.35219/mms.2021.2.02}

Case I: Determination of the stresses in the case of launching the mobile bridge:

$$
\begin{gathered}
\mathrm{H}_{1}=\mathrm{S}^{*} \cos (\alpha)=3.264 \times 10^{4} \\
\mathrm{H}_{1 \mathrm{~d}}=\mathrm{H}_{1} \cdot \mathrm{C}_{\mathrm{d}}=5.222 \times 10^{4} \\
\mathrm{~V}_{1}=\mathrm{S} \cdot(1+\sin (\alpha))=1.008 \times 10^{5} \\
\mathrm{~V}_{1 \mathrm{~d}}=\mathrm{V}_{1} \cdot \mathrm{C}_{\mathrm{d}}=1.613 \times 10^{5}
\end{gathered}
$$

Case II: Determination of the stresses in the case of vertical transport of material:

$$
\begin{gathered}
\mathrm{H}_{2}=\mathrm{S}_{\mathrm{t}} \cdot \cos (\alpha)=1.213 \times 10^{4} \\
\mathrm{H}_{2 \mathrm{~d}}=\mathrm{H}_{2} \cdot \mathrm{C}_{\mathrm{d}}=1.941 \times 10^{4} \\
\mathrm{~V}_{2}=\mathrm{S}_{\mathrm{t}} \cdot(1+\sin (\alpha))=3.747 \times 10^{4} \\
\mathrm{~V}_{2 \mathrm{~d}}=\mathrm{V}_{2} \cdot \mathrm{C}_{\mathrm{d}}=5.996 \times 10^{4}
\end{gathered}
$$

\section{Verification of the tower}

For the winding installation equipped with skip, the height of the winding tower, $H_{T}$, in $m$, from the ground to the upper platform on which the winding pulley is extracted, is calculated by the formula:

$$
\mathrm{H}_{\mathrm{t}}=\mathrm{h}_{\mathrm{r}}+\mathrm{h}_{\mathrm{c}}+\mathrm{h}_{\mathrm{s}}+\frac{\mathrm{D}_{\mathrm{m}}}{2} \text {, in } \mathrm{m}
$$

where: $h_{r}$ represents the positioning height of the skip discharge ramp and material loading, in $\mathrm{m}$. The material is loaded in vehicles by means of a loading chute, so that $h_{r}=8 \mathrm{~m}$ is adopted [3]; $h_{c}$ - skip height together with the safety hook, the cable connecting device (to the upper clamp) and the skip guiding device, in $\mathrm{m}$. Summing up the dimensions of the elements mentioned, $h_{c}=5.550 \mathrm{~m}$ results [4]; $h_{s}$ safety space in case the skip is over lifted, as a result of a handling error, in $\mathrm{m}$, which is adopted at the value $h_{s}=1.45 \mathrm{~m}$, imposed by the labour safety regulations, specific to small speed values; $D_{M}$ diameter of the winding pulley, in $\mathrm{m}, \mathrm{D}_{\mathrm{M}}=2000 \mathrm{~mm}$.

Fig. 2 shows the constructive dimensions and critical sections of the tower [2].

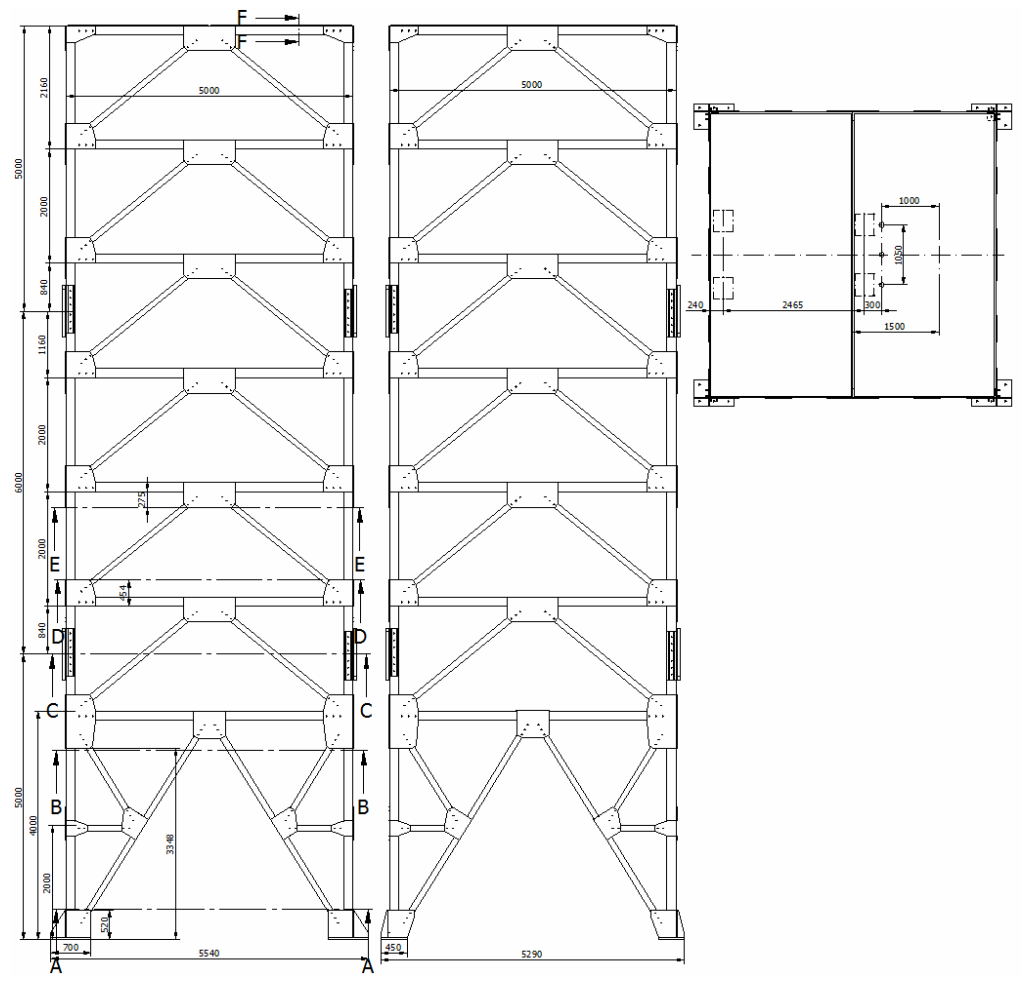

Fig. 2. Constructive dimensions of the tower

Establishing the geometrical characteristics of the critical transoms of the tower and the results of the modelling and simulation in specialised software are succinctly presented in Fig. 3-7. 
Thus in Fig. 3 section A-A through the lower transom of the tower is presented, for which the following geometrical characteristics have been established:

- Inertia moment for axis $\mathrm{X}-\mathrm{X}$, in $\mathrm{mm}^{4}$ is 213611970443.74;

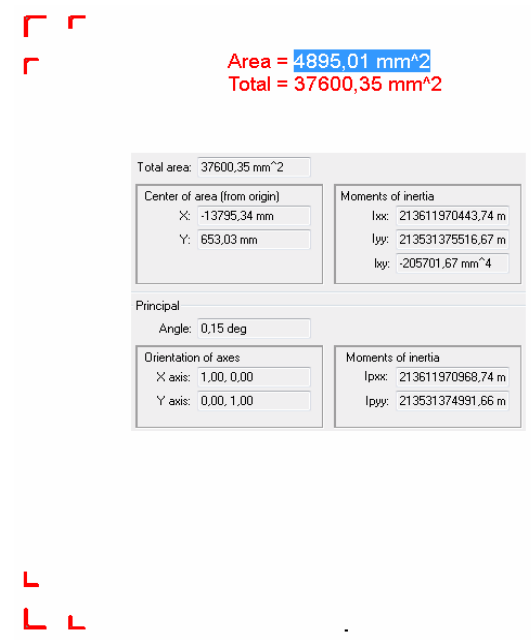

- Inertia moment for axis $\mathrm{Y}-\mathrm{Y}$, in $\mathrm{mm}^{4}$ is 213531375516.67;

- Section area, in $\mathrm{mm}^{2}$ is 37800.35 ;

- Maximum distance, in $\mathrm{mm}$ is 2500 ;

- Resistance module, in $\mathrm{mm}^{3}$ $\mathrm{W}_{\mathrm{xA}}=8.544 \times 10^{7}$ and $\mathrm{W}_{\mathrm{yA}}=8.541 \times 10^{7}$.

Fig. 3. Geometrical characteristics of section A-A through the lower transom of the tower

Fig. 4 shows section B-B through the lower transom of the tower.

In Fig. $4 \mathrm{~A}-\mathrm{A}$ through the lower transom of the tower, for which the following geometric characteristics have been established:

- Inertia moment for axis $\mathrm{X}-\mathrm{X}$, in $\mathrm{mm}^{4}$ equal to 267807002222.8;

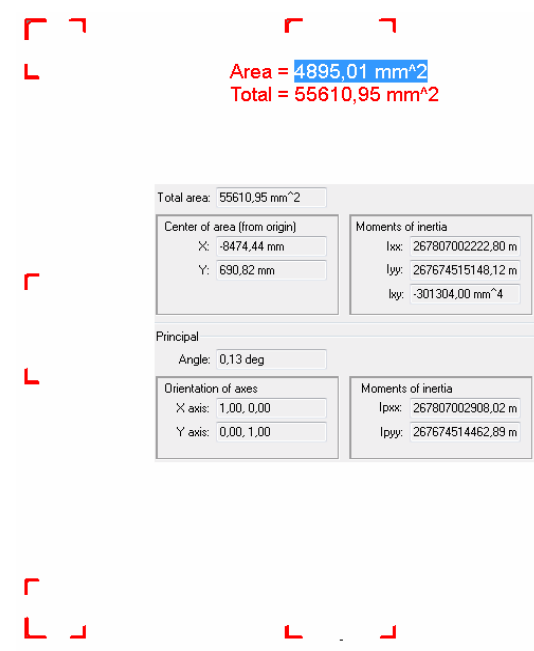

- Inertia moment for axis $\mathrm{Y}-\mathrm{Y}$, in $\mathrm{mm}^{4}$ equal to 267674515148.12;

- Section area, in $\mathrm{mm}^{2}$ equal to 55610.95 ;

- Maximum, in mm equal to 2500 ;

- Resistance module, in $\mathrm{mm}^{3}$ $W_{\mathrm{xB}}=1.071 \times 10^{8}$ and $W_{\mathrm{yB}}=1.071 \times 10^{8}$.

Fig. 4. Geometrical characteristics of section B-B through the lower transom of the tower

In Fig. 5 section $\mathrm{C}-\mathrm{C}$ is presented through the joining area of the lower transom with the intermediary transom of the tower, for which the following geometric characteristics have been established:

- Inertia moment for axis $\mathrm{X}-\mathrm{X}$, in $\mathrm{mm}^{4}$ equal to 310565505011.8; 
- Inertia moment for axis $\mathrm{Y}-\mathrm{Y}$, in $\mathrm{mm}^{4}$ equal to 310565310834.47;

- Section area, in $\mathrm{mm}^{2}$ equal to 60352.53 ;

- Maximum distance, in mm equal to 2566;

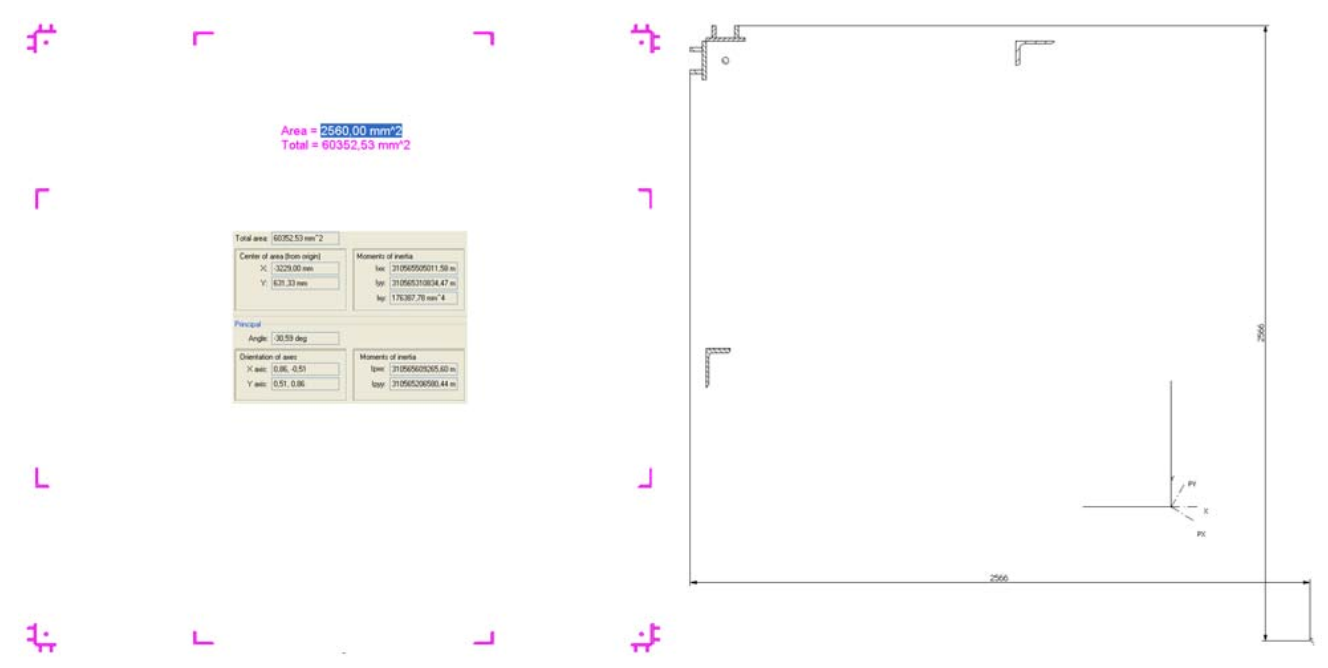

- Resistance module, in $\mathrm{mm}^{3} \mathrm{~W}_{\mathrm{xC}}=1.21 \times 10^{8}$ and $W_{\mathrm{yc}}=1.21 \times 10^{8}$.

Fig. 5. Characteristics of section C-C by joining lower and intermediate transoms of the tower

Fig. 6 shows sections D-D and E-E by the intermediary transom of the tower, for which the following geometric characteristics have been established:

Geometric characteristics at section D-D:

- Inertia moment for axis $\mathrm{X}-\mathrm{X}$, in $\mathrm{mm}^{4}$ equal to 241920563998.18;
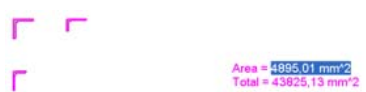

- Inertia moment for axis $\mathrm{Y}-\mathrm{Y}$, in $\mathrm{mm}^{4}$ equal to 241921289707.71;

- Section area, in $\mathrm{mm}^{2}$ equal to 43825.13 ;

- Maximum distance, in mm equal to 2500 ;

- Resistance module in $\mathrm{mm}^{3}$ $W_{\mathrm{xD}}=9.677 \times 10^{7}$ and $W_{\mathrm{yD}}=9.677 \times 10^{7}$.

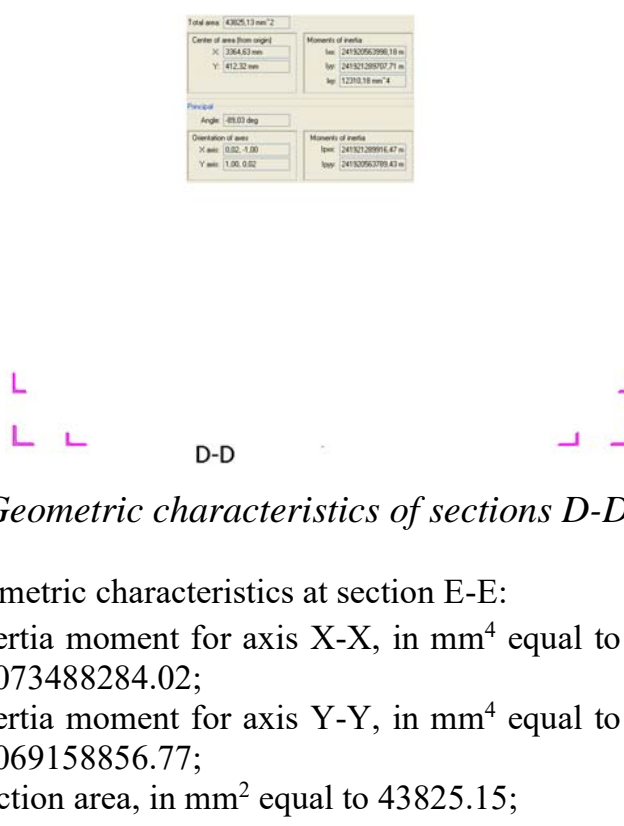

L

ᄂ ᄂ

Geometric characteristics at section E-E:

- Inertia moment for axis $\mathrm{X}-\mathrm{X}$, in $\mathrm{mm}^{4}$ equal to 195073488284.02;

- Inertia moment for axis $\mathrm{Y}-\mathrm{Y}$, in $\mathrm{mm}^{4}$ equal to 195069158856.77;

- Section area, in $\mathrm{mm}^{2}$ equal to 43825.15 ;
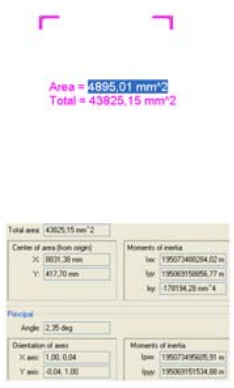

\urcorner

E-E

\llcorner

Fig. 6. Geometric characteristics of sections D-D and E-E through intermediary transom of the tower 
- Inertia moment for axis $\mathrm{X}-\mathrm{X}$, in $\mathrm{mm}^{4}$ equl to 139159414.63;

- Inertia moment for axis Y-Y,in $\mathrm{mm}^{4}$ equal to 120254491995.14;

- Section area, in $\mathrm{mm}^{2}$ equal to 50707.8;
- Maximum distance, in mm equal to 128.39 ;

- Resistance module, in $\mathrm{mm}^{3} \mathrm{~W}_{\mathrm{xF}}=4.81 \times 10^{6}$ and $\mathrm{W}_{\mathrm{yF}}=1.084 \times 10^{7}$.

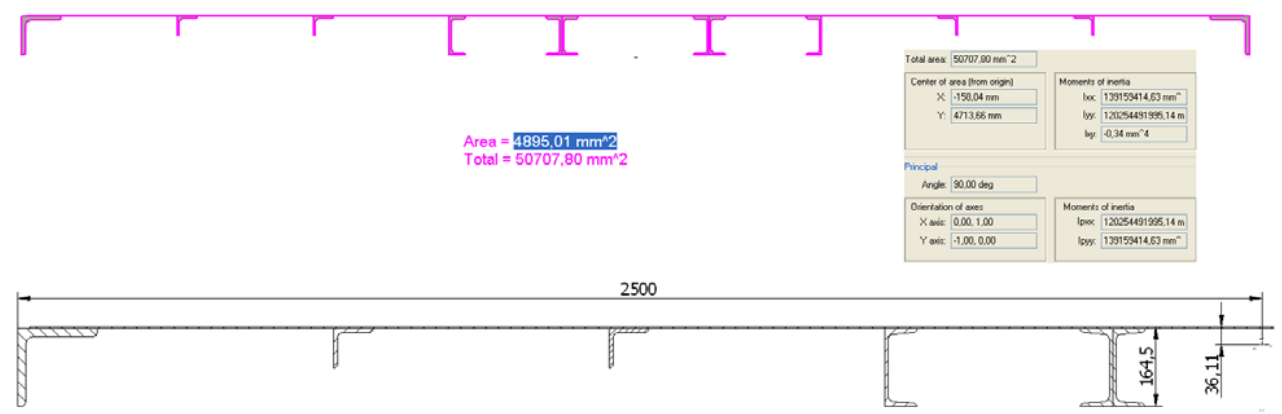

Fig. 7. Geometric characteristics of section F-F through the upper platform of the tower

By all the simulations and from the above mentioned succinctly presented facts, it was pointed out that the maximum values calculated and those resulted from simulations fall into the value range prescribed by the standards and norms in force in the moment of construction and exploitation of the winding machines.

\section{Conclusions}

The metal structure of the winding tower is modelled as a plane framework, which represent a simple undetermined static system, loaded with technological forces that occur in the winding cable and with mass forces given by the weight of the tower.

Maximum technological forces, applied in the symmetry centre of the winding pulley are calculated for two situations, a first case, for the rock transport by skip, and the second, to launch the mobile working bridge or take it out. Considering the importance of the installation, the safety norms impose a safety coefficient of more than 3 , especially that people are also transported, so that the calculations adopt a dynamic coefficient of 1,6 by which the module of the technological forces used in the calculation of the metal structure is multiplied.

Thus, for the verification calculation of the winding tower, the components of the technological forces applied in the centre of the pulley are Fx =
$19410 \mathrm{~N}$ and $\mathrm{Fz}=59960 \mathrm{~N}$, for the case of the transport of the material by skip and $\mathrm{Fx}=52220 \mathrm{~N}$ and $\mathrm{Fz}=161300 \mathrm{~N}$, for the launching of the mobile working bridge or taking it out.

The tower weight is defined by the vector oriented according to axis $\mathrm{z}$, having the module as sum of component elements weights, and the point of application calculated function of the weight centres of the component's elements.

Maximum tensions in the resistance structure of the tower occur in the area of the upper platform, this being demonstrated by the application of the methods of study of the stresses and deformations with the help of finite elements as well as, by using Cosmos Design Star and Abaqus utilities.

\section{References}

[1]. Adam C. D., Instalaţii de extracţie miniere, Partea I-a, II-a, Editura Universitas, Petroșani, 2008.

[2]. Băduț M., Iosip M., Bazele proiectării cu Solid Edge, Editura Albastră, Cluj-Napoca, 2003.

[3]. Buzdugan Gh., Rezistenţa materialelor, Editura Didactică şi Pedagogică, Bucureşti, 1986.

[4]. Itu V., Dumitrescu I., Ridzi M. C., Magyari A., Solicitări mecanice tehnologice ale turnurilor de extracţie miniere, Editura Edyro Press, Petroșani, 2008.

[5]. Magyari A., Achim M. I., Culegere de caracteristici tehnice pentru alegerea şi proiectarea instalaţiilor de extracţie miniere, Litografia Institutului de Mine Petroșani, 1988.

[6]. ***, COSMOS Design STAR Basic User's Guide.

[7]. ***, Solid Edge Software v.19. Academic license ADA Computers. 